\title{
BONE GRAFTS AND BONE SUBSTITUTES
}

Basic Science and Clinical Applications 
This page is intentionally left blank 


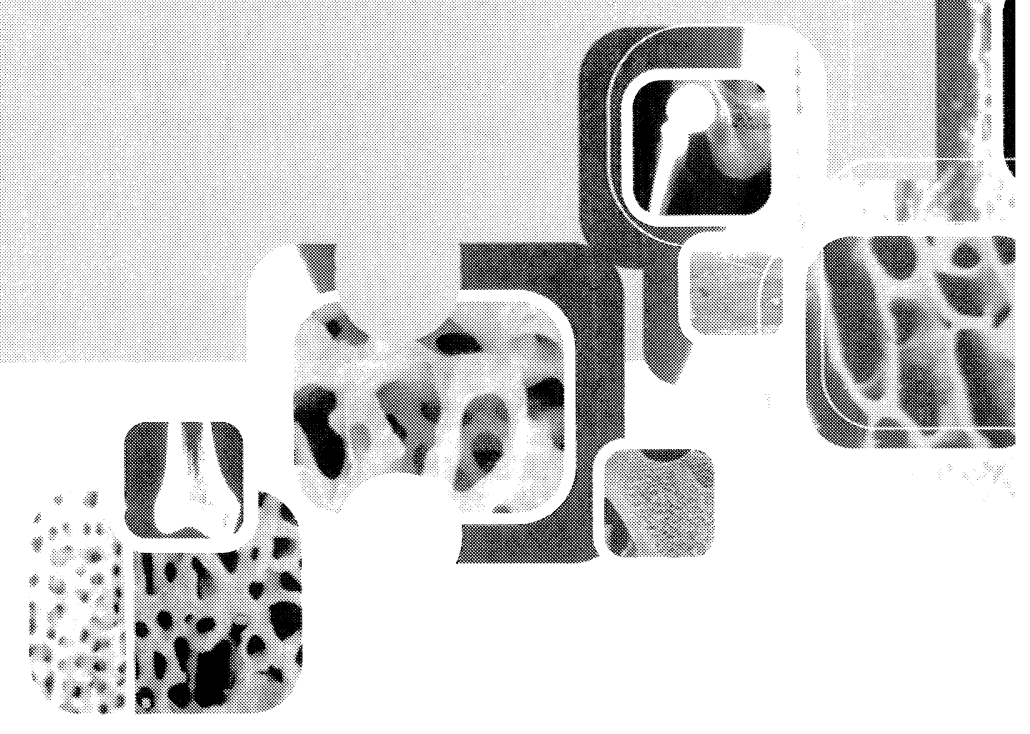

\title{
BONE GRAFTS AND \\ BONE SUBSTITUTES
}

Basic Science and Clinical Applications

\author{
Edited by \\ Aziz Nather
}

National University of Singapore, Singapore

\section{Noworld Scientific}




\author{
Published by \\ World Scientific Publishing Co. Pte. Ltd. \\ 5 Toh Tuck Link, Singapore 596224 \\ USA office: 27 Warren Street, Suite 401-402, Hackensack, NJ 07601 \\ UK office: 57 Shelton Street, Covent Garden, London WC2H 9HE
}

\title{
British Library Cataloguing-in-Publication Data
}

A catalogue record for this book is available from the British Library.

\section{BONE GRAFTS AND BONE SUBSTITUTES \\ Basic Science and Clinical Applications}

Copyright $(\mathcal{C} 2005$ by World Scientific Publishing Co. Pte. Ltd.

All rights reserved. This book, or parts thereof, may not be reproduced in any form or by any means, electronic or mechanical, including photocopying, recording or any information storage and retrieval system now known or to be invented, without written permission from the Publisher.

For photocopying of material in this volume, please pay a copying fee through the Copyright Clearance Center, Inc., 222 Rosewood Drive, Danvers, MA 01923, USA. In this case permission to photocopy is not required from the publisher.

ISBN $981-256-089-0$

Typeset by Stallion Press

Email: enquiries@stallionpress.com 


\section{Contents}

Preface $\quad$ ix

Introduction $\quad$ xi

A Nather

Contributors

xiii

\section{SECTION I: BASIC SCIENCE OF BONE}

Chapter 1 Structure of Bone

A Nather, HJC Ong and Z Aziz

Chapter 2 Fracture Healing

A Nather, MCB Feng and Z Aziz

Chapter 3 An Introduction to Biomechanics of Bone

$B P$ Pereira and A Thambyah

\section{SECTION II: AUTOGRAFTS}

Chapter 4 Autogenous Bone Grafting in Orthopaedic Surgery $K L$ Pan and S Ibrahim

Chapter 5 Vascularised Pedicular Bone Grafts PB Chacha

Chapter 6 Vascularised Autograft: Basic Sciences and

Clinical Applications

$Y K$ Kang and $Y G$ Chung

Chapter 7 Healing of Large, Non-Vascularised, Cortical Autologus Bone Transplants: An Experimental Study in Adult Cats 


\section{SECTION III: ALLOGRAFTS}

Chapter 8 Role of Bone Allografts in Orthopaedic Surgery

A Nather and Z Aziz

Chapter 9 Setting Up a Tissue Bank

A Nather and LH Wang

Chapter 10 Quality Control Issues in Tissue Banking N Hilmy

Chapter 11 Is the Irradiation Dose of $25 \mathrm{kGy}$ Enough to Sterilise Tissue Grafts?

N Yusof

Chapter 12 Diploma Course Training of Tissue Bank

Operators: 7 Years of Experience

A Nather, WY Teo and LH Wang

Chapter 13 Healing of Large Diaphyseal Deep-Frozen

Cortical Allografts

227

A Nather

Chapter 14 Bone Allotransplantation: Future Directions

SM Kumta, PC Leung and LK Fu

\section{SECTION IV: GENOMICS}

Chapter 15 The Human Genome

$S$ Aziz, BC Lin and A Nather

Chapter 16 Genomics in Orthopaedics

A Nather, S Aziz and F Kagda

Chapter 17 Gene Therapy and New Bone Formation

LHC Tsai, SYE Neo and A Nather

\section{SECTION V: BONE TISSUE ENGINEERING}

Chapter 18 Stem Cell Technology and its Commercial Potential 
Chapter 19 Setting Up a Tissue Engineering Laboratory

A Nather, CW Lee and $Z Q$ Tang

Chapter 20 Culturing Mesenchymal Stem Cells from Bone Marrow 321

A Nather, S Das De and CW Lee

Chapter 21 Bone Marrow Derived Mesenchymal Stem Cells:

Potential for Tissue Regeneration

$J$ Rosocha, G Vaško, G Varga and D Harvanová

Chapter 22 Scaffolds in Bone Tissue Engineering

A Nather and S Aziz.

Chapter 23 Carriers of Mesenchymal Cells

A Nather and V David

\section{SECTION VI: GROWTH FACTORS}

Chapter 24 The Role of Bone Morphogenic Proteins in

Bone Incorporation

A Nather and A Dutton

Chapter 25 Platelet-Rich Plasma in Orthopaedic Surgery:

Basic Science and Clinical Applications

$S$ Das De, R Manohara and A Nather

Chapter 26 Applications of Autogenous Platelet Rich

Plasma (PRP) Gel to Enhance Bone Formation

405

C-J Yim

\section{SECTION VII: CERAMICS}

Chapter 27 The Need for New Materials for Use in Bone in Man

PA Revell, E Damien

Chapter 28 Role of Ceramics as Bone Graft Substitutes

$V$ David, A Nather and KA Khalid

Chapter 29 Enhancement of the Bioactivity of Orthopaedic

Biomaterials: Role of Growth Factors, Ion

Substitution and Implant Architecture

E Damien and PA Revell 
Chapter 30 Fabrication of Granular Hydroxyapatite F Fazan

Chapter 31 Role of Corals and Coralline Ceramics in Orthopaedic Surgery

$V$ David, A Nather and KA Khalid

Chapter 32 Biomedical Use of Corals and Coralline

Hydroxyapatite in Hard Tissue Replacement

E Damien and PA Revell

Chapter 33 Coral as Bone Graft Substitute

SA Hamid, AR Samsudin, $R$ Salim and N Omar

\section{SECTION VIII: PROSTHESES}

Chapter 34 Rapid Prototyping in Orthopaedics: Principles and Applications

$J$ Abdullah and AY Hassan

Chapter 35 Custom Mega Prosthesis for Bone Reconstruction in Orthopaedic Surgery

MV Natarajan, M Paraskumar and G Rajkumar

Index 


\section{Preface}

This book discusses Bone Grafting using autografts from non-vascularised grafts to pedicled ones and free vascularised bone grafts and the various options to bone grafting ie. the use of bone substitutes. The latter ranges from Allografts, Genomics in Orthopaedic Practice with particular reference to Bone Formation, Tissue Engineering including all 3 elements of the triad Cells, Scaffolds and Signalling Molecules to Ceramics and Prostheses. The section of Ceramics include some results from the ten million ringgit MultiCentre Research Project in Malaysia namely the fabrication of Malaysian Hydroxyapatite and the development of Malaysian Coral.

This book is useful to clinicians and clinician scientists in the field of Orthopaedics, Plastic and Reconstructive Surgery and Maxillo-Facial Surgery who are commonly presented with the clinical problem of reconstructing large bone defects. It is also useful to research scientists namely tissue engineers and biomedical engineers pursuing the field of research on bone substitutes in the field of allograft transplantation, genomics of bone, bone tissue engineering and the development of new generation bioceramics and new prostheses.

Associate Professor Aziz Nather 
This page is intentionally left blank 


\title{
Introduction
}

\author{
A Nather
}

Bone Grafting is one of the commonest operations performed in Orthopaedics. Its indications include non-union, delayed union, packing bone cysts and cavities, elevating depressed articular fractures and reconstruction of large bone defects. Autografting from the iliac crest is the gold standard. However, due to limitations as to amount, size and shape of the graft that could be procured as well as associated donor site morbidity, bone substitutes have become extremely important and useful for Orthopaedic Surgery, Plastic Reconstructive Surgery and Maxillo-Facial Surgery.

Section I first addresses the Basic Science of Bone including the structure of bone and the biomechanics of bone and the repair process that occurs in fracture healing.

Autografts are discussed in detail in Section II including the method of performing autogenous bone grafting and its diverse clinical applications. The ipsilateral pedicled bone graft and also the free vascularised bone graft are covered in detail. The healing of large non-vascularised cortical bone transplants is also described.

Section III deals with a common bone substitute - Allografts. Allografts have served this function very well for the last 5 decades. A useful chapter especially for Universities who have not set up a tissue bank is the chapter on "Setting Up a Tissue Bank" which serves as a useful guide to all wishing to establish a new bone banking facility. Issues of quality control for allografts, value of gamma irradiation to sterilize the bone grafts and the training of tissue bank operators are addressed in detail. Biology 
and biomechanics of healing of cortical allografts and the future of bone allotransplantation is also described.

Section IV introduces the field of Genomics and discusses the use of Genomics in Orthopaedic Practice with particular reference to bone formation.

Bone Tissue Engineering is covered in depth in Section V including methodology for culturing Mesenchymal Stem Cells, types of scaffolds used and types of carriers employed for transplantation of cells.

In Section VI the third element of the Tissue Engineering Triad is addressed, namely signalling Molecules or Growth Factors. The role of BMPs and PRP are discussed.

Section VII covers Ceramics. Its scope ranges from the need of new biomaterials to the role of Hydroxyapatite, Coral and Coralline Ceramics as bone substitutes. The fabrication of the Malaysian Hydroxyapatite and the Malaysian Coral recently developed are also described.

Finally, this book on Bone Graft Substitutes would not be complete without discussing one other option, namely Prostheses. Rapid prototyping techniques and the use of Custom MegaProstheses are described in Section VIII. 


\section{Contributors}

\author{
Suzina Sheikah ABDUL HAMID \\ Consultant, Ear, Nose and Throat \\ Department \\ Malaysian National Tissue Bank \\ School of Medical Sciences, Universiti \\ Sains Malaysia Health Campus \\ Kota Bharu, Kelantan, Malaysia
}

\section{Jamaluddin ABDULLAH}

School of Mechanical Engineering

University of Sciences Malaysia -

Engineering Campus

Seri Ampangan, 14300 Nibong Tebal

Seberang Perai Selatan, Penang,

Malaysia

\section{Sharnaz AZIZ}

Laboratory Technologist

Department of Orthopaedic Surgery

National University of Singapore

10 Kent Ridge Crescent

Singapore 119260

\section{Zameer AZIZ}

Laboratory Technologist

Department of Orthopaedic Surgery

National University of Singapore

10 Kent Ridge Crescent

Singapore 119260

\section{P.B. CHACHA}

Consultant Orthopaedic Surgeon

Mount Elizabeth Hospital

3 Mount Elizabeth

Singapore 228510

CHANG-Joon Yim, DDS

MSD, PhD

ENE Implant Center

Youngil Bldg. \#201, Seochodong

1675-13, Seochoku

Seoul, 137-070, Republic of Korea

\section{Yong Guk CHUNG}

Department of Orthopaedic Surgery

Catholic University Medical College

St. Vincent's Hospital

Suwon, 440-060, Korea

\section{Elsie DAMIEN}

Biomaterials and Tissue Engineering, Eastman Dental Institute, UCL, London WC1X 8LD, UK

\section{Soumen DAS DE, MBBS}

Medical Officer

Department of Orthopaedic Surgery

National University of Singapore

10 Kent Ridge Crescent

Singapore 119260 
Vikram DAVID, MBBS, MS (Orth)

Medical Officer

Department of Orthopaedic Surgery

National University Hospital

5 Lower Kent Ridge Road

Singapore 119074

\section{Andrew Quoc DUTTON, MBBS,} FRCS (Ortho)

Registrar

Department of Orthopaedic Surgery

National University Hospital

5 Lower Kent Ridge Road

Singapore 119074

\section{Fazilah FAZAN}

AMREC, SIRIM Berhad,

Lot 34, Jln Hi-Tech 2/3

Kulim Hi-Tech Park,

09000 Kulim, Kedah, Malaysia

\section{FENG Min Chin Bernard}

Laboratory Technologist

Department of Orthopaedic Surgery

National University of Singapore

10 Kent Ridge Crescent

Singapore 119260

\section{L.K. FU, MBBS, MPhil}

Department of Orthopaedics and

Traumatology

The Chinese University of Hong Kong

Shatin NT, Hong Kong, China

\section{Denisa HARVANOVÁ}

Faculty of Medicine

The Pavol Jozef Safarik University and University Hospital

Trieda SNP 1

04066 Kosice, Slovak Republic
Ahmad Yusoff HASSAN

School of Mechanical Engineering

University of Sciences Malaysia -

Engineering Campus

Seri Ampangan, 14300 Nibong Tebal

Seberang Perai Selatan, Penang,

Malaysia

\section{Nazly HILMY, PhD}

Batan Research Tissue Bank,

Centre for Research and Development of Isotopes and Radiation Technology Batan, Jakarta

Sharaf IBRAHIM, MD, FRCS, MS (UKM)

Associate Professor and Paediatric

Orthopaedic Surgeon

Department of Orthopaedics

University Kebangsaan Malaysia

Kuala Lumpur, Malaysia

Fareed Hussain KAGDA, MBBS, FRCS (Ortho)

Consultant

Department of Orthopaedic Surgery

National University Hospital

5 Lower Kent Ridge Road

Singapore 119074

Yang Koo KANG, MD, PhD

Professor

Department of Orthopaedic Surgery

Catholic University Medical College

St. Vincent's Hospital

Suwon, 440-060, Korea

\section{Kamarul Ariffin KHALID}

Lecturer

Department of Orthopaedic Surgery

International Islamic University of

Malaysia

Kuantan, Malaysia 
Shekhar M KUMTA, MS (Orth), PhD

Associate Professor

Department of Orthopaedics and

Traumatology

The Chinese University of Hong Kong

Shatin NT, Hong Kong, China

\section{LEE Choon Wei Chris}

Laboratory Officer

Department of Orthopaedic Surgery

National University of Singapore

10 Kent Ridge Crescent

Singapore 119260

\section{P.C. LEUNG, FRCS, DSe}

Department of Orthopaedics and

Traumatology

The Chinese University of Hong Kong

Shatin NT, Hong Kong, China

\section{LIN Bitong Clarabelle}

Laboratory Technologist

Department of Orthopaedic Surgery

National University of Singapore

10 Kent Ridge Crescent

Singapore 119260

\section{Ruben MANOHARA, MBBS}

Medical Officer

Department of Orthopaedic Surgery

National University Hospital

5 Lower Kent Ridge Road

Singapore 119074
Mayil Vahanan NATARAJAN, MBBS, D Orth (Ma's), M Ch

Trauma Orth (Liverpool), PhD (Orth Onco)

Professor

Head, Department of Orthopaedic

Surgery

Madras Medical College

Periyar EVR Salai

Park Town, Chennai

Tamil Nadu, India 600003

Aziz NATHER, MBBS, FRCS (Ed), FRCS (Glas), AM, MD

Associate Professor

Department of Orthopaedic Surgery

National University of Singapore

10 Kent Ridge Crescent

Singapore 119260

\section{SYE NEO}

Department of Orthopaedic Surgery

National University Hospital

5 Lower Kent Ridge Road

Singapore 119074

\section{Reida EI OAKLEY}

Associate Professor

Department of Surgery

National University of Singapore

10 Kent Ridge Crescent

Singapore 119074

\section{Nor Shamsuria OMAR}

Malaysian National Tissue Bank

School of Medical Sciences, Universiti

Sains Malaysia Health Campus

Kota Bharu, Kelantan, Malaysia 


\section{ONG Hui Jing Christine}

Laboratory Technologist

Department of Orthopaedic Surgery

National University of Singapore

10 Kent Ridge Crescent

Singapore 119260

\section{PAN Kok Long}

Professor

Head, Department of Orthopaedics

University Malaysia Sarawak

Kuching, Sarawak, Malaysia

\section{PARASKUMAR}

Department of Orthopaedic Surgery

Madras Medical College

Periyar EVR Salai

Park Town, Chennai

Tamil Nadu, India 600003

\section{Barry PEREIRA, M. Eng}

Research Fellow

Department of Orthopaedic Surgery

National University Singapore

10 Kent Ridge Crescent

Singapore 119260

\section{G. RAJKUMAR}

Department of Orthopaedic Surgery

Madras Medical College

Periyar EVR Salai

Park Town, Chennai

Tamil Nadu, India 600003

\section{Shanaz RAUFF}

University of Pennsylvania

USA

\section{Peter A REVELL}

Biomaterials and Tissue Engineering,

Eastman Dental Institute, UCL,

London WC1X 8LD, UK

\section{Jan ROSOCHA, DVM, CSc}

Head of Associated Tissue Bank

Faculty of Medicine

The Pavol Jozef Safarik University

and University Hospital

Trieda SNP 1

04066 Kosice, Slovak Republic

\section{Rosdan SALIM}

Consultant, Ear, Nose and Throat

Department

Malaysian National Tissue Bank

School of Medical Sciences, Universiti

Sains Malaysia Health Campus

Kota Bharu, Kelantan, Malaysia

\section{Abdul Rani SAMSUDIN}

Dean, Faculty of Dentistry

Director, Malaysian National Tissue

Bank

School of Medical Sciences, Universiti

Sains Malaysia Health Campus

Kota Bharu, Kelantan, Malaysia

\section{TANG Zhi Qun}

Laboratory Officer

Department of Orthopaedic Surgery

National University of Singapore

10 Kent Ridge Crescent

Singapore 119260

\section{TEO Wan Yee}

Laboratory Technologist

Department of Orthopaedic Surgery

National University of Singapore

10 Kent Ridge Crescent

Singapore 119260 
Ashvin THAMBYAH, M.Eng, M.Sc

Research Fellow

Department of Orthopaedic Surgery

National University Singapore

10 Kent Ridge Crescent

Singapore 119260

TSAI Hui Ching Larry, MBBS

Medical Officer

Department of Orthopaedic Surgery

National University Hospital

5 Lower Kent Ridge Road

Singapore 119074

\section{Gabriel VARGA}

Faculty of Medicine

The Pavol Jozef Safarik University and University Hospital Trieda SNP 1

04066 Kosice, Slovak Republic
Gabriel VAŠKO, MD, CSc

Associate Professor

Faculty of Medicine

The Pavol Jozef Safarik University

and University Hospital

Trieda SNP 1

04066 Kosice

Slovak Republic

\section{WANG Li Hui}

Senior Laboratory Technologist

NUH Tissue Bank

National University Hospital

5 Lower Kent Ridge Road

Singapore 119074

\section{Norimah YUSOF, BSc, MSc, $\mathrm{PhD}$}

Director of Agrotechnology \&

Biosciences Division

Malaysian Institute for Nuclear

Technology Research (Mint)

Bangi, 43000 Kajang

Selangor, Malaysia 